\title{
Effect of Crude Oil and Petroleum-degrading Micro-organisms on the Growth of Freshwater and Soil Protozoa
}

\author{
By ANDREW ROGERSON AND JACQUES BERGER* \\ Department of Zoology, University of Toronto, Toronto, Ontario M5S 1A1, Canada
}

(Received 14 July 1980; revised 17 October 1980)

\begin{abstract}
Growth responses of six species of freshwater and soil protozoa were determined for cells grown monoxenically on various petroleum-utilizing microflora. Protozoa were cultured either in the presence or absence of partially degraded crude oil. The regression coefficient characterizing the slope of the growth curve was used as a comparison index throughout. The nature of the prey species determined the magnitude of the protozoan growth response. The presence of crude oil did not consistently raise or lower an individual species' rate of division. Crude oil had no overall influence on protozoan size although there was a slight tendency towards larger cells in the presence of oil.
\end{abstract}

\section{INTRODUCTION}

Marine oil spillages may be treated with booms, skimmers, sorbants, chemical barriers or dispersants. Such options, however, are usually ineffective in freshwater or soil environments (Cox \& Cowell, 1979). Seeding spills with efficient strains of oil-degrading micro-organisms is an alternative strategy now under investigation (Jong et al., 1979; La Rock \& Severence, 1973; Yall, 1979). Such action may result in 'blooms' of a specific oil-utilizing microbiota leading to possible health problems because some petroleum-degrading species are known to be potential vertebrate pathogens (Beamar et al., 1976; Qureshi \& Dutka, 1979). Even a policy of inaction results in an increase in the number of oil-utilizing species (Bartha \& Atlas, 1977). As a consequence of the intimate association between bacteria and grazing protozoa, it is important to understand the implications of an oil spill at this level in the food chain.

The present study was undertaken primarily to investigate the ability of a known oil-degrading microflora to support the growth of several common freshwater and soil protozoa. Secondarily, these protozoa were cultured with emulsified crude oil to determine the effects of directly ingesting oil globules, as demonstrated by Andrews \& Floodgate (1974) for marine ciliates.

\section{METHODS}

Organisms. The growth responses of five ciliate species were investigated: Colpidium campylum (Stokes), Tetrahymena pyriformis GL (Ehrenberg), Colpidium colpoda (Ehrenberg), Colpoda cucullus (Müller) and Uroleptus sp. In addition, the growth of the soil amoeba Naegleria gruberi (Schärdinger) was determined. Colpoda cucullus and Uroleptus sp. were isolated directly from soil contaminated with oil-sludge (Shell Refinery, Oakville, Ontario, Canada). The two Colpidium species were derived from clones used in previous growth studies (Taylor, 1978, 1979; Taylor \& Berger, $1976 a, b$ ), while Tetrahymena pyriformis and Naegleria gruberi were subcultured from existing stocks maintained by Drs A. M. Zimmerman and S. Corff, respectively (University of Toronto, Ontario, Canada). Mass ciliate cultures were routinely maintained at $20^{\circ} \mathrm{C}$ in $0.1 \%(\mathrm{w} / \mathrm{v})$ cerophyl medium. The powdered cereal leaves of cerophyl (Cerophyl Laboratories, Kansas City, Mo., U.S.A.) suspended in distilled water were autoclaved at $125^{\circ} \mathrm{C}$ for $15 \mathrm{~min}$ and filtered using $0.45 \mu \mathrm{m}$ pore-size membrane filters (Schleicher \& Schuell, Keene, N.H., U.S.A.). The mass ciliate cultures were maintained on a mixed microflora with Enterobacter aerogenes as the predominant prey species. Naegleria gruberi was maintained axenically at $20^{\circ} \mathrm{C}$ (Fulton, 1974). 
Eight oil-degrading micro-organisms were obtained from Professor W. R. Finnerty, University of Georgia, Athens, Ga., U.S.A.: the bacteria Pseudomonas aeruginosa, Acinetobacter $\mathrm{C}_{6}$, Acinetobacter $\mathrm{HO} 1-\mathrm{N}$ and Corynebacterium foster; the actinomycetes Nocardia 179, Nocardia 72 and Mycobacterium album; and the yeast Candida tropicalis. Enterobacter aerogenes and Pseudomonas sp. were obtained from K. Chua of the Royal Ontario Museum, Toronto, Ontario, Canada. All were maintained on nutrient agar (Difco) slopes.

Determination of growth rate in the absence of crude oil. To investigate the growth response of protozoa to individual species of known oil-utilizing micro-organisms, ciliates and amoebae were cultured monoxenically under controlled conditions of temperature and food supply. Prey micro-organisms were prepared by culturing in $0.1 \%$ $(\mathrm{w} / \mathrm{v})$ cerophyl medium for $24 \mathrm{~h}$ at $22 \pm 1{ }^{\circ} \mathrm{C}$. The turbidity was measured and adjusted with sterile medium to between 6 and 10 Nephelometric Turbidity Units (NTU). The linear relationship between turbidity and cell count was determined empirically (unpublished results) and permitted consistency in the initial prey concentration $\left(100 \times 10^{6}\right.$ to $200 \times 10^{6}$ cells $\left.\mathrm{ml}^{-1}\right)$.

Erlenmeyer flasks $(125 \mathrm{ml})$ contained $50 \mathrm{ml}$ cerophyl medium and a known species and number of prey. Ciliates were washed free of contaminating bacteria by micropipetting cells through eight changes of sterile medium. Between transfers, cells were left for at least $30 \mathrm{~min}$ to permit bacteria to be emptied from their food vacuoles. A known number of washed ciliates (between 5 and 20) was added to each flask. Their growth rate was monitored by periodically counting the number of cells $\mathrm{ml}^{-1}$ with a Sedgwick-Rafter counting chamber (Hausser Scientific, $\mathrm{Pa}$., U.S.A.). Initially, the ciliate population was low and the entire chamber was scanned. When their concentration increased above $20 \mathrm{ml}^{-1}$, this method was modified. By moving the microscope stage, the mean number of ciliates [fixed in $4 \%(\mathrm{w} / \mathrm{v})$ glutaraldehyde] in 20 randomly selected replicate visual fields was determined. Conversion factors of $\times 216.45$ and $\times 1351.35$ for magnifications of $\times 60$ and $\times 150$, respectively, expressed the recorded counts as cells $\mathrm{ml}^{-1}$.

Five replicate flasks, shaken at 120 strokes $\mathrm{min}^{-1}$, were used for each experimental condition investigated. Control flasks containing sterile cerophyl medium and washed ciliates were used to monitor the sterility of the protozoan population under investigation. On those occasions when control flasks became contaminated, the results of the accompanying experimental series were discarded. In addition, flask contents were frequently examined by Gram-staining to ensure that protozoa remained monoxenic.

The experimental method for Naegleria gruberi was similar although no washing was required as amoebae were maintained axenically. Bacterial cultures were inoculated with $25 \mu \mathrm{l}$ of a dense suspension of Naegleria gruberi ( 500 to 1500 cells $\mathrm{ml}^{-1}$ ). Flasks were not shaken because cell attachment is required for amoeboid phagocytosis.

Determination of growth rate in the presence of crude oil. The experiments described above were repeated in the presence of partially microbially-degraded Norman Wells crude oil (Imperial Oil, Norman Wells, N.W.T., Canada). Erlenmeyer flasks $(500 \mathrm{ml})$ containing $200 \mathrm{ml}$ cerophyl and $2 \%(\mathrm{v} / \mathrm{v})$ crude oil were inoculated with a monospecific suspension of the required hydrocarbon-utilizing micro-organism. Emulsification of the oil fraction in the aqueous phase was apparent after growth for $30 \mathrm{~d}$ at $22 \pm 1{ }^{\circ} \mathrm{C}$ and was used as evidence of microbial activity. The emulsified oil was allowed to settle before diluting the prey suspension to the reference concentration of 6 to 10 NTU. Protozoa were then added and their growth was monitored.

Semi-logarithmic regressions (base 10 ) of the cell counts against time were computed for the exponential phase of growth, based on between 25 and 35 data points. This permitted expression of specific growth rates $(b)$ with the units $\mathrm{h}^{-1}$. Comparisons of cell size were made for all ciliates showing a positive growth response to the treatments. Fifty ciliates in the late-exponential phase of growth were fixed in $4 \%(\mathrm{w} / \mathrm{v})$ glutaraldehyde and measured along their longitudinal and transverse axes with an ocular micrometer at $\times 150$.

Additional treatments. The toxicity of the hydrocarbon fraction alone was investigated by culturing Tetrahymena pyriformis axenically in enriched proteose peptone medium (Szyszko et al., 1968) with and without crude oil.

\section{RESULTS}

The growth of five ciliate species and an amoeba cultured with ten oil-degrading micro-organisms was compared in the presence and absence of crude oil (Table 1). The bacteria Enterobacter aerogenes, Acinetobacter $\mathrm{C}_{6}$, Pseudomonas aeruginosa, Pseudomonas sp. and Acinetobacter HO1-N generally supported growth. Conversely, Nocardia 72, Corynebacterium foster, Mycobacterium album and the yeast Candida tropicalis were unsuitable as a diet, although Colpoda cucullus did grow on the latter two species. Some species displayed neither growth nor cell lysis during the $14 \mathrm{~d}$ experimental period (Table 1). Such responses were common when Nocardia 179 was the prey organism.

Possible enhancement or retardation of growth due to oil stress was explored by comparing the $b$-coefficients calculated from the observed growth curves. A single 
Table 1. Growth of six protozoan species on ten oil-degrading prey micro-organisms when cultured in the absence and presence of crude oil

\begin{tabular}{|c|c|c|c|c|c|c|c|c|c|c|c|}
\hline & & \multicolumn{10}{|c|}{ Growth response* } \\
\hline & & \multicolumn{10}{|c|}{ Prey species } \\
\hline & Crude oil & 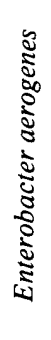 & 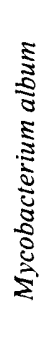 & 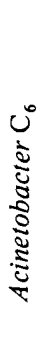 & 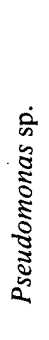 & 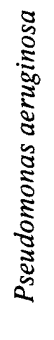 & 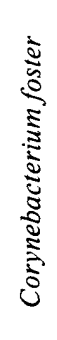 & 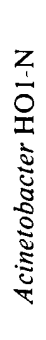 & 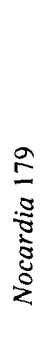 & 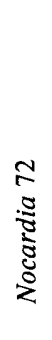 & 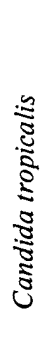 \\
\hline \multirow[t]{2}{*}{ Colpidium campylum } & Absent & + & - & + & + & + & - & + & - & - & - \\
\hline & Present & + & - & + & + & + & - & + & + & - & - \\
\hline \multirow[t]{2}{*}{ Colpidium colpoda } & Absent & + & - & + & + & + & - & + & - & - & - \\
\hline & Present & + & - & + & + & + & - & + & 0 & - & - \\
\hline \multirow[t]{2}{*}{ Colpoda cucullus } & Absent & + & + & + & + & + & - & + & + & 0 & + \\
\hline & Present & + & + & + & + & + & - & + & - & - & - \\
\hline \multirow[t]{2}{*}{ Tetrahymena pyriformis } & Absent & + & - & + & + & + & - & + & - & - & - \\
\hline & Present & + & - & + & + & + & - & + & 0 & - & - \\
\hline \multirow[t]{2}{*}{ Uroleptus sp. } & Absent & + & - & + & + & + & - & + & - & - & - \\
\hline & Present & + & - & 0 & + & + & - & + & 0 & - & - \\
\hline \multirow[t]{2}{*}{ Naegleria gruberi } & Absent & + & - & + & + & + & - & $\mathrm{C}$ & - & - & - \\
\hline & Present & + & - & + & + & + & - & + & - & - & - \\
\hline
\end{tabular}

${ }^{*}+$, positive growth response; --, cell lysis; 0 , intermediate response, i.e. neither growth nor lysis; C, premature encystment of amoebae.

classification analysis of variance (Sokal \& Rohlf, 1969) found all regressions to be highly significant $(P<0.001)$. Variation among the five replicate flasks was as follows: from a comparison of ten randomly selected data sheets, the standard errors of the mean cell counts between replicate flasks typically ranged from 4.0 to $39 \%$ of the mean values. Additional variation was introduced because it was impractical to obtain an absolute protozoan count at high cell densities. In this case the average protozoan count, derived from 20 visual fields, typically ranged from 4.8 to $20 \%$ about this mean value. The $b$-coefficients for pairs of positive growth responses in the presence and absence of oil were compared on the basis of overlap between their $95 \%$ confidence regions (Fig. 1). This pattern is presented in Fig. 2 which compares the regression coefficients $(b)$ for protozoa grown under the same conditions of prey both in the presence and absence of oil. Theoretically, if the effect of crude oil was negligible, all points should lie on the straight line $(y=x)$. The $b$-coefficients of $45 \%$ of the total points are similar and are correspondingly close to this line (Fig. 2). Values below the line show that oil significantly retarded growth and vice versa for points above the line. However, the distribution of points below (34\%) and above $(21 \%)$ are such that no consistent effect attributable to oil can be discerned.

The influence of oil on the size of exponentially growing ciliates was not consistent (Fig. 3) as dissimilar points (differing by more than 2 S.E.M.) lie both above (34.6\%) and below $(15.4 \%)$ the line $y=x$. This distribution indicates a slight tendency towards larger cell size for protozoa cultured with emulsified oil.

The individual responses of protozoa to a range of acceptable prey species varied. Disregarding oil as a toxic factor, the calculated generation times ranged from 3.06 to $5.92 \mathrm{~h}$ $\left(b=0.098\right.$ to $\left.0.051 \mathrm{~h}^{-1}\right)$ for Tetrahymena pyriformis, 4.09 to $8.75 \mathrm{~h}(b=0.073$ to 


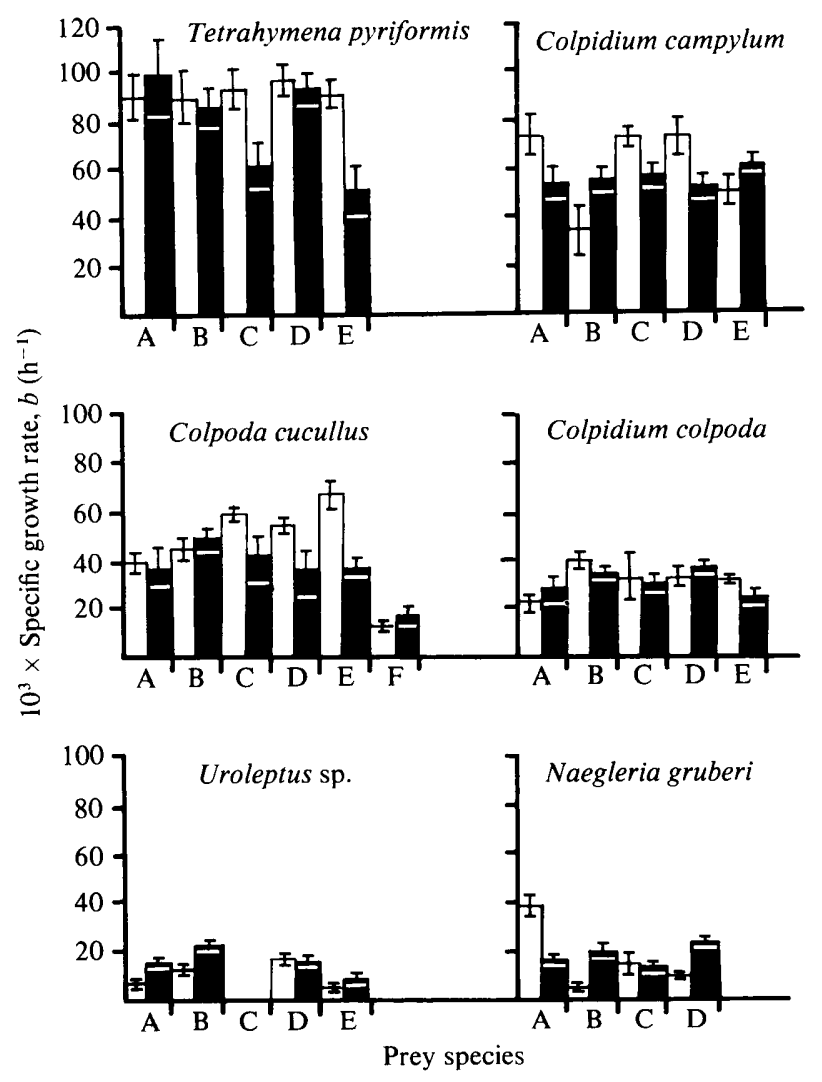

Fig. 1. Specific growth rates (with $95 \%$ confidence regions) of five ciliates and an amoeba grown monoxenically on a range of bacteria: Enterobacter aerogenes (A), Pseudomonas sp. (B), Acinetobacter $\mathrm{C}_{6}(\mathrm{C})$, Pseudomonas aeruginosa (D), Acinetobacter HO1-N (E), Mycobacterium album (F). The solid bars indicate growth in the presence of crude oil; open bars represent growth in the absence of oil.

$\left.0.034 \mathrm{~h}^{-1}\right)$ for Colpidium campylum, 7.70 to $14.34 \mathrm{~h}\left(b=0.039\right.$ to $\left.0.021 \mathrm{~h}^{-1}\right)$ for Colpidium colpoda, 4.59 to $24.16 \mathrm{~h}\left(b=0.065\right.$ to $\left.0.012 \mathrm{~h}^{-1}\right)$ for Colpoda cucullus, 13.22 to $77.18 \mathrm{~h}(b$ $=0.023$ to $\left.0.004 \mathrm{~h}^{-1}\right)$ for Uroleptus sp. and 12.02 to $55.90 \mathrm{~h}\left(b=0.025\right.$ to $\left.0.005 \mathrm{~h}^{-1}\right)$ for Naegleria gruberi. Again, disregarding the effect of oil, the microbial prey promoting maximum growth was not consistent for each protozoan species (Fig. 1). Tetrahymena pyriformis and Naegleria gruberi grew most rapidly on Enterobacter aerogenes; Colpidium colpoda and Uroleptus sp. grew best on Pseudomonas sp.; Colpidium campylum favoured Pseudomonas aeruginosa; while Acinetobacter HO1-N promoted maximum growth in Colpoda cucullus. The slow growth rates of Colpoda cucullus in the presence of Mycobacterium album $\left(b=0.012\right.$ and $\left.0.016 \mathrm{~h}^{-1}\right)$ and Nocardia $179\left(b=0.021 \mathrm{~h}^{-1}\right)$ were expected as these microbial species were usually unacceptable food items (Table 1). In contrast, the reproductive rate of Colpidium campylum cultured with Nocardia 179 was high $\left(b=0.073 \mathrm{~h}^{-1}\right)$.

The additional treatment of growing axenic Tetrahymena pyriformis with and without oil confirmed that dissolved hydrocarbon components had no appreciable effect on the rate of cell increase. The $b$-coefficient describing growth in proteose peptone medium alone was $0.039 \pm 0.003 \mathrm{~h}^{-1}$ (95\% confidence limits), while the presence of oil made no significant difference $\left(b=0.040 \pm 0.005 \mathrm{~h}^{-1}\right)$. 


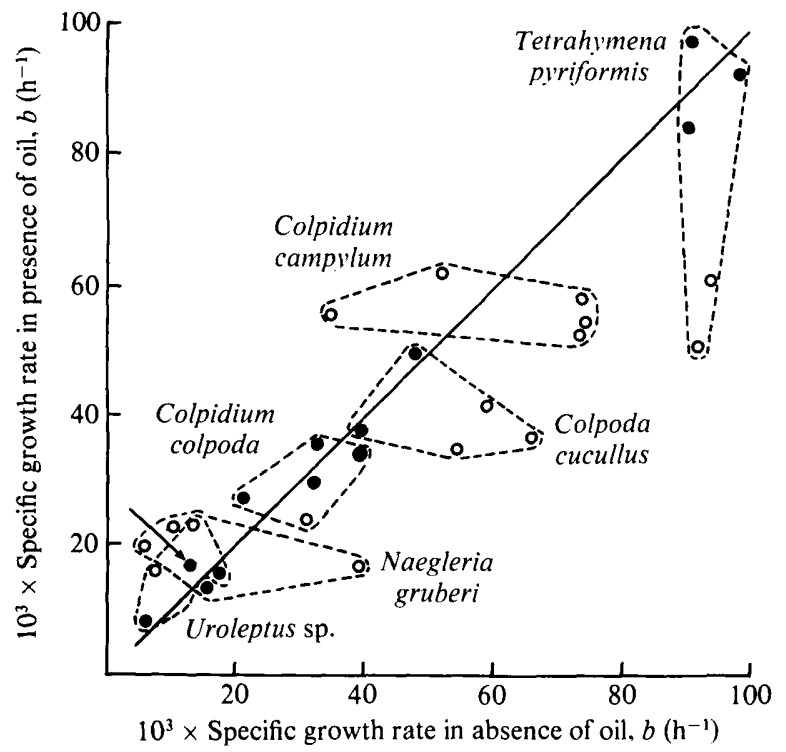

Fig. 2. Effect of crude oil on the specific growth rate of protozoa. Each symbol refers to a pair of regression coefficients $(b)$ calculated for protozoa cultured monoxenically in the absence and presence of crude oil. The symbols indicate pairs of positive responses yielding $b$-coefficients with overlapping $95 \%$ confidence regions. The growth rates did not overlap at this level for the $O$ symbols. The arrow refers to a value for Colpoda cucullus. Theoretically, if oil has no effect on growth, all points should lie on the straight line $(y=x)$.

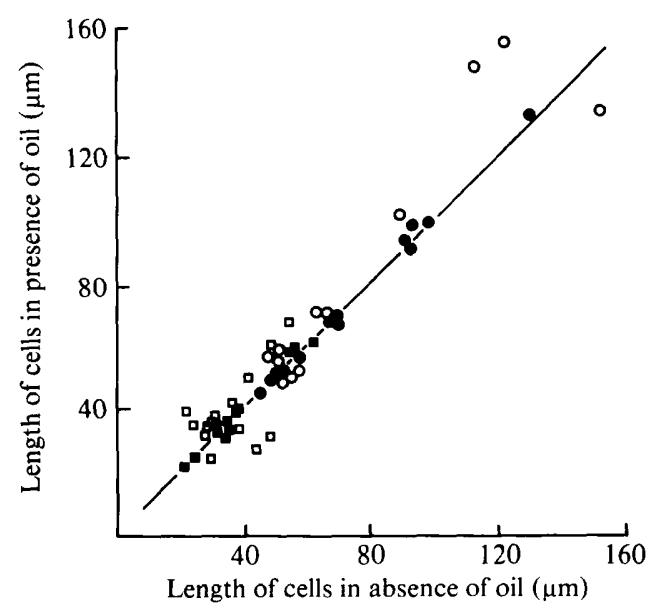

Fig. 3. Comparison of the lengths of the cells of the five ciliate species yielding positive growth responses when cultured in the absence and presence of crude oil. Each symbol refers to the mean length of the cells' longitudinal axes $(\mathbf{O}, \mathbf{O})$ and transverse axes $(\square, \square)$. The filled symbols are used where the $95 \%$ confidence regions overlapped. The straight line $(y=x)$ is included for reference.

\section{DISCUSSION}

This is the first study to analyse the consequences of rearing protozoa on a diet of hydrocarbon-degrading micro-organisms, both with and without oil fractions. Prior studies have highlighted both the suitability and inadequacy of several bacterial species for the 
monoxenic growth of ciliates (Barna \& Weis, 1973; Curds \& Vandyke, 1966; Taylor, 1979; Taylor \& Berger, 1976b). The present investigation, however, is the first to concentrate on known oil-utilizing micro-organisms. The results indicate clearly that the protozoan growth response was dependent on the prey species consumed. Of the ten hydrocarbon-degrading species used in culture, only five could be classed as supporting predator replication. These were exclusively bacterial species yielding protozoan growth rates comparable with those reported by Finlay (1977) and Taylor \& Berger (1976a).

The presence of hydrocarbons in our batch culture system had no consistent effect on the protozoan growth response. The oil droplets observed within the food vacuoles of ciliates grown in emulsified culture (A. Rogerson \& J. Berger, unpublished results) did not deter protozoan replication. The slight tendency for ciliates to increase their cell size in the presence of oil (Fig. 3) may be due to this internal hydrocarbon concentration which can be readily observed using ultraviolet light microscopy (Andrews \& Floodgate, 1974). This suggests that the growth of these microconsumers in oil-polluted areas may be instrumental in the transfer of oil fractions within the food web. Furthermore, recent ultrastructural evidence has demonstrated cytoplasmic membrane-bound hydrocarbon inclusions in Acinetobacter grown with petroleum (Scott \& Finnerty, 1976; Yall, 1979). As bacteria are the predominant diet of ciliated protozoa (Wichterman, 1953) and many soil amoebae, it is expected that the consumption of oil-degrading prey in the polluted environment would lead to further bioaccumulation of oil fractions by protozoa. This is especially true in view of the growth rates displayed by protozoa cultured with oil-degrading bacteria.

The actinomycetes Mycobacterium album, Nocardia 179 and Nocardia 72, as well as the yeast Candida tropicalis, were nutritionally inadequate for sustaining monoxenic growth of the majority of protozoa examined. Although growth was found when Colpoda cucullus was cultured with Mycobacterium album, the rate of increase was slow $(b=0.012$ and $\left.0.016 \mathrm{~h}^{-1}\right)$. The prey's morphology may have inhibited ingestion, particularly in the case of the nocardias which produced large bacillary and coccoid cells after fragmentation of their mycelia. Furthermore, adding oil to nocardial and yeast cultures promoted mycelial growth, rendering them largely unsuitable as dietary items. Protozoa may also have lacked the enzymes necessary for digesting certain prey, while the consistently negative results obtained using Corynebacterium foster as prey suggest the secretion of a microbial toxin. The action of such toxins on the growth of ciliates has been described previously (Curds \& Vandyke, 1966). Colpoda cucullus was the only species capable of utilizing the yeast Candida tropicalis as prey. However, this is consistent with the feeding behaviour of Colpoda spp. on Saccharomyces (Sandon, 1932). The failure of Colpoda cucullus to grow on yeast in the presence of crude oil was probably due to the formation of 'pseudomycelia' under such culture conditions. The reproductive rate of Colpidium campylum cultured with Nocardia 179 was high $(b=$ $\left.0.073 \mathrm{~h}^{-1}\right)$. No suitable explanation can be offered to clarify this inconsistent response. Similarly, the premature encystment of Naegleria gruberi cultured with Acinetobacter $\mathrm{HO} 1-\mathrm{N}$ remains unexplained.

The protozoa most susceptible to reduced growth rates in the presence of emulsified oil were the small pelagic ciliates, Tetrahymena pyriformis, Colpidium campylum and Colpoda cucullus. It is probable that ingestion of oil globules temporarily reduced their assimilation efficiency and, hence, their growth. Conversely, replication of the hypotrich, Uroleptus sp., was enhanced in three of the oil treatments. The increased surface area offered by the dispersed oil droplets to degrading bacteria may have benefitted this browsing ciliate.

Jong et al. (1979) have recently evaluated the possibility of freeze-drying Candida tropicalis and several other hydrocarbon-utilizing yeasts for seeding oil spills. The dietary acceptability of such species to protozoa must first be determined if the adverse ecological effects of monospecific 'blooms' are to be avoided. 
assistance, Ms P. E. Bregman for her editorial advice, Dr K. Chua and Professor W. R. Finnerty for supplying microbial cultures, Drs S. Corff and A. M. Zimmerman for protozoan stocks, Dr M. A. Gates for statistical advice and Dr D. Mackay for supplying the crude oil.

\section{REFERENCES}

Andrews, A. R. \& Floodgate, G. D. (1974). Some observations on the interaction of marine protozoa and crude oil residues. Marine Biology 25, 7-12.

BARNA, I. \& WeIs, D. S. (1973). The utilization of bacteria as food for Paramecium bursaria. Transactions of the American Microscopical Society 92, 434-440.

Bartha, R. \& AtLas, R. M. (1977). The microbiology of aquatic oil spills. Advances in Applied Microbiology 22, 225-266.

Beamar, B. L., Burnside, J., Edwards, B. \& Causey, W. (1976). Nocardial infections in the United States, 1972-1974. Journal of Infectious Diseases 134, 286-299.

Cox, G. V. \& Cowell, E. B. (1979). Mitigating oil spill damage - ecologically responsible clean-up techniques. In Proceedings of the American Fisheries Society, Technical Report RM-65, pp. 121128. Washington, D.C.: United States Department of Agriculture.

Curds, C. R. \& VAndyke, J. M. (1966). The feeding habits and growth rates of some freshwater ciliates found in activated sludge plants. Journal of Applied Ecology 3, 127-137.

Finlay, B. J. (1977). The dependence of reproductive rate on cell size and temperature in freshwater ciliated protozoa. Oecologia 30, 75-81.

Fulton, C. (1974). Axenic cultivation of Naegleria gruberi. Requirement for methionine. Experimental Cell Research 88, 365-370.

Jong, S.-C., Roxon, J. \& Simone, JR, F. (1979). Freeze-dried hydrocarbon-utilizing yeasts for possible use in artificial seeding of oil spills. Hydrobiologia 64, 175-178.

LA Rock, P. A., \& Severence, M. (1973). The bacterial treatment of oil spills: the facts considered. In Estuarine Microbial Ecology, p. 309. Edited by L. H. Stevenson \& R. R. Colwell. Columbia, South Carolina, U.S.A.: University of South Carolina Press.
Qureshl, A. A. \& DutKa, B. J. (1979). Microbiological studies on the quality of urban stormwater runoff in southern Ontario, Canada. Water Research 13, 977-985.

Sandon, H. (1932). The Food of Protozoa. Publications of the Faculty of Science of the Egyptian University, Cairo 1, 1-187.

Scott, C. C. L. \& Finnerty, W. R. (1976). Characterization of intracytoplasmic hydrocarbon inclusions from the hydrocarbon-oxidizing Acinetobacter, species HO1-N. Journal of Bacteriology 127, 481-489.

SOKAL, R. R. \& RohlF, F. J. (1969). Biometry, pp. 204-252. San Francisco, U.S.A.: W. H. Freeman \& Co.

Szyszko, A. H., Prazak, B. L., Ehret, C. F., Eisler, W. J. \& Wille, J. J. (1968). A multi-unit sampling system and its use in the characterization of ultradian and infradian growth in Tetrahymena. Journal of Protozoology 15, 781-785.

TAYLOR, W. D. (1978). Growth responses of ciliate protozoa to the abundance of their bacterial prey. Microbial Ecology 4, 207-214.

TAYLOR, W. D. (1979). Overlap among cohabiting ciliates in their growth responses to various prey bacteria. Canadian Journal of Zoology 57, 949-951.

TAYLOR, W. D. \& BERGER, J. (1976a). Growth of Colpidium campylum in monoxenic batch culture. Canadian Journal of Zoology 54, 392-398.

TAYLOR, W. D. \& Berger, J. $(1976 b)$. Growth responses of cohabiting ciliate protozoa to various prey bacteria. Canadian Journal of Zoology 54, 1111-1114.

Wichterman, R. (1953). The Biology of Paramecium. New York \& Toronto: Blakiston Co.

YALL, I. (1979). A petroleum-eating bacterium. Natural History 88, 41-46. 